\title{
KEPRIBADIAN TOKOH UTAMA DALAM CERPEN SAGA KARYA SHANTINED DARI KUMPULAN CERPEN UN SOIR DU PARIS: KAJIAN PSIKOANALISIS
}

\section{PERSONALITY OF MAIN CHARACTER IN THE SHORT STORY SAGA BY SHANTINED FROM SHORT STORY COLLECTION UN SOIR DU PARIS: PSYCHOANALYSIS STUDIES}

\author{
Tita Nurajeng Miyasari \\ Magister Ilmu Susastra, Fakultas Ilmu Budaya \\ Universitas Diponegoro \\ Jalan Prof Soedarto, S.H. Tembalang Semarang \\ 0817467783; vakha_b@yahoo.com
}

\begin{abstract}
Abstrak
Studi ini menganalisis kepribadian tokoh utama (Aku) dalam cerita pendek Saga, yang ditulis oleh Shantined. Penelitian ini menggunakan teori psikoanalisis Sigmund Freud untuk memahami karakter utama dalam cerpen Saga. Metode yang digunakan adalah metode analisis deskriptif. Tujuan dari penelitian ini adalah untuk mendeskripsikan kepribadian tokoh Aku dari aspek id, ego, dan superego. Hasil penelitian ini menyatakan bahwa id dan ego merupakan peran paling aktif untuk memenuhi hasrat seksual karakter utama. Namun, superego belum bekerja sempurna untuk mengendalikan atau menghambat kerja id dan ego karakter utama. Tokoh utama dalam cerita pendek ini memiliki ketidakseimbangan psikologis karena perilaku dan keinginan homoseksualnya.
\end{abstract}

Kata kunci: psikoanalisis, tokoh utama, Saga

\begin{abstract}
This study analyzes the personality of main character (Aku) in the short story Saga, written by Shantined. Psychoanalysis by Sigmund Freud used as theory to understand the main character of short story Saga. The method used is known as descriptive analytical method. The purpose of this study is to describe the personality of main character from the aspect of id, ego, and superego. The result of this study states that id and ego are the most active role to fulfill the sexual desire of the main character. However, superego has not worked perfectly to control or hamper the workings of id and ego of the main character. The main character in this short story has a psychological imbalance because of her behavior and homosexual desire.
\end{abstract}

Key words: psychoanalysis, main character, Saga

\section{Pendahuluan}

Sastra adalah seni bahasa, yakni cabang seni yang menggunakan bahasa sebagai mediumnya (Danziger dan Johnson dalam Budianta, dkk, 2008:7). Karya sastra dapat memberi manfaat bagi pembaca karena isi karya sastra tak terbatas. Karya sastra dapat berbicara banyak hal, misalnya psikologi. Dengan kata lain, karya sastra dapat memberi pembaca beragam informasi dari cabang ilmu psikologi. Menurut Hassan Shadily (1989: 1090-1091), psikologi adalah ilmu pengetahuan tentang jiwa, yang mempelajari hal ikhwal yang berhubungan dengan kesadaran (consciousness), sensasi (sensation), pikiran (ideation), ingatan (memory), dan sebagainya. Sebagai karya yang imajinatif, karya sastra bisa memperlihatkan tokoh-tokoh yang mewakili perilaku manusia yang beragam. Perilaku manusia yang ada dalam 
kehidupan sehari-hari bisa membantu pengarang dalam menggambarkan karakter tokoh cerita yang ditulisnya. Kepribadian sangat mencerminkan perilaku seseorang. Untuk memahami dan menjelaskan tingkah laku diri sendiri dan orang lain, kita harus memahami definisi kepribadian dan bagaimana kepribadian itu terbentuk sehingga gangguan-gangguan yang biasa muncul pada kepribadian setiap individu dapat dihindari.

Psikologi kepribadian merupakan salah satu ilmu dasar yang penting guna memahami ilmu psikologi. Manusia sebagai objek material dalam pembelajaran ilmu psikologi tentu memiliki kepribadian dan watak yang berbeda satu dengan lainnya bahkan tidak semua orang dapat memahami kepribadian dirinya sendiri. Anshari (1996:131) mendefinisikan watak sebagai suatu ketahanan atau kualitas yang tetap dan dapat dilihat atau dialami oleh seseorang sebagai perangai atau tabiat. Watak tokoh dalam karya sastra adalah kualitas tokoh, kualitas nalar dan jiwanya yang membedakannya dengan tokoh lain (Tuloli, 2000:30). Oleh karena itu, karya sastra tak cukup dikaji melalui perspektif sastra, tetapi juga diperlukan sokongan ilmu lain untuk memahami karya sastra. Pertemuan sastra dengan ilmu psikologi telah melahirkan kajian interdisipliner, yaitu psikologi sastra. Psikologi sastra adalah studi tipe dan hukumhukum psikologi yang kemudian diterapkan pada karya sastra (Wellek \& Warren, 2014). Menurut Semi (1993: 79), pendekatan psikologi sastra adalah pendekatan yang bertolak dari asumsi bahwa karya sastra selalu membahas peristiwa kehidupan manusia. Manusia memperlihatkan beragam perilaku yang muncul karena adanya interaksi dengan manusia lainnya. Pendekatan psikologi banyak berpedoman pada psikoanalisis yang dikembangkan Sigmund Freud yang menyatakan bahwa manusia banyak dikuasai oleh alam batinnya sendiri.

Menurut Freud dalam Rokhmansyah (2013:161), struktur kepribadian manusia mengandung tiga komponen yang disebut id (tidak sadar), ego (tidak sadar, prasadar, sadar), dan superego (tidak sadar, prasadar, sadar). Ketiga sistem kepribadian ini satu sama lain saling berkaitan serta membentuk totalitas dan tingkah laku manusia yang muncul merupakan produksi integrasi ketiganya (Ratna dalam Wicaksono, 2009: 63). Dalam penelitian ini, tokoh akan dikaji ketiga aspek kepribadiannya dengan menggunakan psikoanalisis Sigmund Freud.

Teori psikoanalisis yang dipakai dalam penelitian ini adalah teori yang dicetuskan oleh seorang neurolog berkebangsaan Austria bernama Sigmund Freud pada tahun 1980-an. Teori ini mendewakan sesuatu yang bernama alam bawah sadar atau ketidakssadaran (unconsciousness). Teori ini juga banyak memengaruhi sastrawan dalam penciptaan karya-karya mereka. Alam pikiran bawah sadar ternyata merupakan objek yang menarik karena pada dasarnya merupakan bagian dari jiwa manusia yang sering tanpa disadari memonopoli dirinya. Freud tertarik terhadap eksplorasi psikoanalitik yang semakin luas dan mencoba menemukan cara beroperasinya pikiran manusia yang "normal". Menurut Freud, perilaku yang ditunjukkan manusia hanyalah lapisan luarnya saja dan belum tentu murni. Untuk mengetahui sifat asli manusia, perlu diamati gelagat simbolis dan pikiran yang paling mendalam dari manusia tersebut (Minderop, 2010:9).

Teori ini juga menyatakan seks sebagai sumber insting dasar manusia. Teori Freud tentang seksualitas, tidak semata-mata mengadopsi teori-teori pada zamannya karena Freud tidak saja membicarakan topik tabu (misalnya, homoseksualitas, sadisme, masokisme, hubungan seksual oral dan anal) secara publik, tetapi juga karena ia secara terang-terangan menyatakan bahwa semua "penyimpangan seksual", "variasi", dan "ketidaknormalan", pada dasarnya hanyalah tahapan dalam perkembangan seksualitas manusia normal. Menurut Freud, anak-anak mengalami tahapan perkembangan psikoseksual yang jelas; dan gender dari setiap orang dewasa adalah hasil dari bagaimana ia mengatasi tahapan ini. Maskulinitas dan feminintas, dengan perkataan lain, adalah produk dari pendewasaan seksual.

Psikoanalisis adalah bagian dari psikologi kepribadian. Teori psikoanalisis yang 
dicetuskan oleh Freud menyatakan bahwa perilaku manusia dibentuk oleh naluri-naluri dan konflik-konflik struktur kepribadian (Minderop, 2010:8). Konflik-konflik struktur kepribadian ialah konflik yang timbul dari pergumulan antara id, ego, dan superego (Minderop, 2010:8). Ketiga sistem kepribadian ini satu sama lain saling berkaitan serta membentuk totalias tingkah laku manusia yang merupakan produksi integrasi ketiganya (Ratna dalam Wicaksono, 2009:63). Menurut Freud dalam Rokhmansyah (2013:161), struktur kepribadian manusia mengandung tiga komponen yang disebut id (tidak sadar), ego (tidak sadar, prasadar, sadar), dan superego (tidak sadar, prasadar, sadar). Ketiga komponen ini satu sama lain saling berkaitan serta membentuk totalitas.

Salah satu contoh dari permasalahan psikologi adalah mengenai LGBT (Lesbian, Gay, Bisekual, dan Transgender) yang banyak menimbulkan polemik akhir-akhir ini di Indonesia. LGBT sudah terdengar di Indonesia sekira 1960-an. Dahulu sering dikenal Sentul \& Kantil. Pada saat itu banyak bermunculan organisasi pendukung LGBT, misalnya Himpunan Wadam (Wanita Adam) Djakarta atau biasa disingkat HIWAD, yang pernah diprotes MUI pada era itu (Kurniawan, 2016). Kemudian Lambda Indonesia (didirikan pada 1 Maret 1982) dan organisasi sejenis lainnya bermunculan pada akhir tahun 1980-an dan 1990-an (Ikawati, 2015).

LGBT dalam sastra Indonesia sendiri di mulai pada tahun 1983, ketika Mira W. menerbitkan novel Relung-Relung Gelap Hati Sisi yang menjadikannya novel populer pertama di Indonesia yang mengangkat isu lesbian. Sampai saat ini, novel ini masih terus dicetak ulang dan mencapai cetakan kedelapan. Kisah cinta Airin dan Sisi dalam novel yang terbit pertama kali 34 tahun lalu ini masih menjadi kisah yang relevan untuk dibaca sampai zaman sekarang, tidak hanya oleh pembaca lesbian, tetapi juga untuk pembaca heteroseksual. Tahun 2000-2010 merupakan dekade keemasan fiksi LGBT. Media cetak terlihat lebih leluasa memuat cerpen-cerpen bertema LGBT. Penerbit pun seakan berlomba-lomba menerbitkan novel- novel bertema LGBT. Garis Tepi Seorang Lesbian karya Herlinatiens (2003), Lelaki Terindah karya Andrei Aksana (2004), Ini Dia, Hidup karya Ezinsky (2003), Jangan Beri Aku Narkoba karya Alberthiene Endah (2004) hingga Gerhana Kembar karya Clara Ng (2007).

Cerpen Saga yang akan dianalisis dalam penelitian ini adalah salah satu cerpen dari dua belas cerpen mengenai lesbian yang terangkum dalam buku yang berjudul Un Soir $d u$ Paris. Buku ini diterbitkan pada tahun 2010 oleh Gramedia Pustaka Utama. Cerpen ini ditulis oleh Shantined. Ia lahir di Yogyakarta, 21 Oktober 1972. Beberapa karyanya berupa puisi dimuat di surat kabar. Surat Putih 2 (2003), Surat Putih 3 (2004), Dian Sastro for President 3 (2004), Perkawinan Batu (2004) merupakan beberapa antologi puisinya bersama penulis lain. Sedang cerpennya Bingkisan Petir terbit dalam antologi cerpen Kalimantan Timur. Ia juga aktif di milis-milis puisi dan di Dewan Kesenian Balikpapan.

Penulis memilih cerpen Saga untuk dianalisis lebih lanjut karena tokoh Aku dalam cerpen ini mengalami konflik kejiwaan yang cukup kompleks. Karena hubungan lesbiannya ketahuan oleh keluarganya dan demi menjaga nama baik keluarga, tokoh Aku terpaksa menikah dengan lelaki bernama Erald. Selama hampir delapan tahun usia perkawinan mereka, tokoh Aku tidak merasakan kebahagiaan. Kapan pun Erald mau, ia akan mencumbui tokoh Aku tanpa peduli situasi dan kondisi. Selain itu, Erald juga gemar mabuk dan menyiksa tokoh Aku. Darah mengalir dan luka-luka menganga di tubuh tokoh Aku. Kadang air cuka dan jeruk asam sengaja dikucurkan Erald ke atas luka tokoh Aku. Suatu hari, tokoh Aku menemukan cinta lagi pada seorang perempuan bernama Aini. Mereka bertemu di sebuah kafe di pinggir laut. Tokoh Aku merasa "pulang" ketika mereka sepakat menjalani hari-hari bersama dalam ikatan kasih sayang. Tokoh Aku berjanji tak akan meninggalkan Aini sendiri dan akan mendampinginya sampai kapan pun.

Berdasarkan sinopsis di atas, dapat dilihat bahwa unsur psikologi memang terdapat dalam karya ini. Kajian ini akan difokuskan 
pada tokoh Aku karena tokoh ini selain menjadi tokoh utama juga tokoh yang paling kompleks kejiwaannya di antara semua tokoh. Tokoh Aku adalah seorang lesbian, selain mempunyai seorang suami yang gemar menyiksa, ia juga mempunyai kekasih perempuan yang sangat dicintainya. Adanya konflik kejiwaan pada diri tokoh Aku sangat menarik diteliti. Untuk itu, pendekatan yang tepat digunakan adalah teori psikoanalisis Sigmund Freud. Melalui pendekatan ini, dapat diketahui konflik antara id, ego, dan superego di dalam diri tokoh Aku.

Lesbian adalah perempuan yang mencintai dan merasakan rangsangan seksual sesama jenisnya (KBBI, 2008:820). Lesbian juga merupakan istilah bagi perempuan yang mengarahkan pilihan orientasi seksualnya kepada sesama perempuan atau disebut juga perempuan yang mencintai perempuan baik secara fisik, seksual, emosional, atau spriritual. Lesbianisme didefinisikan bukan sekadar faktor alamiah, tetapi lebih kepada masalah preferensi seksual berdasarkan pengalaman perempuan yang dapat terjadi kapan saja dalam hidup perempuan (JP, 2008: 147-148).

Oetomo (dalam Susilandari, 2009) menjelaskan, lesbianisme adalah sekelompok sosial yang terpinggirkan dalam masyarakat karena orang tidak bisa menerima orientasi homoseksual. Orientasi seksual mereka dianggap menyimpang dalam hal aspek psikologis, aspek sosial, budaya, dan agama. Mereka tidak hanya dianggap sebagai penyimpangan, tetapi juga sebagai individu sakit. Ketidaktahuan dan ketakutan terhadap LGBT membuat orang berbondong-bondong menjadi polisi susila, seakan-akan LGBT adalah penyakit yang harus ditumpas. Berbagai ancaman dan tindak kekerasan yang terjadi pada kaum LGBT Indonesia dianggap sebagai hal yang lumrah. Sesungguhnya menurut acuan diagnostik para ahli psikiatri di Indonesia dalam Pedoman Penggolongan dan Diagnosis Gangguan Jiwa Edisi II (PPDGJ II) Departemen Kesehatan Republik Indonesia tahun 1983 dan PPDGJ III tahun 1993, orientasi seksual (homoseksual, heteroseksual, biseksual) bukanlah gangguan kejiwaan (Rusli, 2017).
Seperti yang telah dijelaskan sebelumnya, untuk menganalisis kepribadian tokoh Aku, diperlukan bantuan ilmu psikologi, yaitu teori psikoanalisis Sigmund Freud. Berdasarkan latar belakang masalah di atas, maka masalah penelitian ini adalah bagaimana kepribadian tokoh utama cerpen Saga karya Shantined dari aspek id, ego, dan superego dalam kajian psikoanalisis Sigmund Freud. Penelitian ini bertujuan untuk mendeskripsikan kepribadian tokoh utama cerpen Saga karya Shantined dari aspek id, ego, dan superego dalam kajian psikoanalisis Sigmund Freud.

Sudah banyak penelitian dalam bentuk jurnal, skripsi, maupun tesis yang menganalisis kepribadian tokoh utama dengan menggunakan teori psikoanalisis Sigmund Freud. Skripsi "Analisis Tokoh Gambir dalam Novel Pintu Terlarang: Sebuah Tinjauan Psikologi Sastra" oleh Amalia (2014) yang menyimpulkan bahwa perilaku abnormal yang ditunjukkan oleh Gambir dipicu oleh pengalaman masa kecilnya. Penyiksaan yang ia terima selama anak-anak membuat id-nya tidak puas. Ia pun menyingkirkan sumber ketidakpuasannya, yakni kedua orangtuanya. Gambir membunuh kedua orangtuanya. Id telah menguasainya sehingga ego tidak dapat memberikan jalan keluar yang bijaksana. Jurnal "Kajian Psikoanalisis dalam Novel Pria Terakhir Karya Gusnaldi" yang ditulis oleh Novrita (2017) menyimpulkan antara aspek id, ego dan superego dalam diri tokoh utama tidak seimbang, sehingga kelainan seks yang dimilikinya terus dipertahankan tanpa berusaha untuk menekannya atau menghilangkannya.

Berdasarkan penjelasan mengenai penelitian-penelitian terdahulu, belum ditemukan penelitian yang membahas cerpen Saga karya Shantined menggunakan teori psikoanalisis Sigmund Freud. Melalui pembacaan yang telah dilakukan, terlihat bahwa cerpen Saga memuat konflik kejiwaan tokoh Aku yang seorang lesbian. Konflik kejiwaan tokoh Aku dalam cerpen Saga mungkin mewakili kejiwaan kaum LGBT yang demi menjaga nama baik keluarga, terpaksa menikah dengan orang yang tidak mereka cintai. Konflik kejiwaan antara id, ego, 
dan superego inilah yang akan menjadi bahan kajian dalam penelitian ini, sekaligus sebagai pembeda penelitian ini dengan penelitianpenelitian lain yang pernah dilakukan sebelumnya.

\section{Metode}

Jenis penelitian ini adalah penelitian kualitatif dengan menggunakan metode deskriptif. Semi (1993:23) menjelaskan bahwa penelitian kualitatif adalah penelitian yang dilakukan dengan tidak menggunakan angka-angka, tetapi lebih mengutamakan penghayatan peneliti terhadap interaksi antarkonsep yang sedang dikaji secara empiris. Objek material penelitian ini adalah cerpen Saga karya Shantined yang merupakan satu dari dua belas cerpen dalam buku kumpulan cerpen lesbian berjudul Un Soir du Paris yang terbit pada 2010 dan diterbitkan oleh PT Gramedia Pustaka Utama di Jakarta, sedangkan objek formalnya kata atau kalimat berupa ungkapan maupun peristiwa yang menggambarkan kejiwaan tokoh Aku yang meliputi id, ego, dan superego. Teknik analisis data yang dilakukan dalam penelitian ini adalah sebagai berikut: (1) klasifikasi data berdasarkan id, ego, dan superego; (2) analisis data berdasarkan id, ego, dan superego; (3) interpretasi data; (4) menyimpulkan; dan (5) membuat laporan penelitian.

\section{Hasil dan Pembahasan}

Menurut teori psikoanalisis, id, ego, dan superego adalah tiga sistem yang pasti bekerja dalam diri individu ketika individu merespons suatu peristiwa. Jadi, sebuah peristiwa terjadi karena ada respons dari individu terhadap peristiwa sebelumnya. Respons yang diberikan adalah hasil dari kompromi id, ego, dan superego. Dalam karya sastra, selama cerita masih berjalan, berarti tokoh masih memiliki respons terhadap peristiwa sebelumnya. Karena itulah, penulis akan menganalisis id, ego, dan superego tokoh Aku dari awal cerita hingga akhir cerita.

Berikut ini adalah pengertian dari ketiga sistem utama kepribadian psikoanalisis menurut Sigmund Freud sekaligus analisisnya dalam cerpen Saga berdasarkan kepribadian tokoh Aku yang merupakan tokoh utama dalam cerpen ini.

\subsection{Id}

Id merupakan watak dasar pada setiap manusia yang hadir sejak manusia lahir dan berisi sifatsifat keturunan, naluri seksual, dan agresif. Id cenderung menghendaki penyaluran atau pelampiasan untuk setiap keinginan, yang jikalau tertahan atau tersumbat, akan mengalami ketegangan. Oleh sebab itu, yang dikenal id adalah prinsip kesenangan dan penyalurannya dengan cara yang implusif, irasional, serta narsistik, dengan tanpa mempertimbangkan akibat atau konsekuensi. Watak ini juga tidak mengenal rasa takut dan cemas sehingga tindakan hati-hati tidak diperlukan di dalam upaya penyaluran hasrat keinginan (Siswantoro, 2005:38-39).

Id pada manusia menghasilkan kecenderungan untuk agresif dan terfokus pada pemenuhan kebutuhan jasmani. Id adalah bagian dari sistem yang dihasilkan oleh tubuh untuk memenuhi kebutuhannya. Id seluruhnya berada pada alam bawah sadar. Id sering ditafsirkan sebagai insting seperti pada hewan. Namun, insting berbeda dengan id. Oleh Freud, id disebut sebagai "triebe" atau dalam arti harfiahnya drive (dorongan). Dorongan inilah yang menurut Freud mengendalikan dan menentukan kemampuan, kualitas, dan kapasitas seseorang. Kalau id seseorang itu tinggi, maka kualitas orang tersebut secara keseluruhan dengan sendirinya akan tinggi. Usaha yang dilakukan oleh orang dengan id yang tinggi lebih baik jika dibandingkan dengan usaha yang dilakukan oleh orang yang id-nya rendah. Karena orang dengan id tinggi berusaha untuk memenuhi kebutuhan hidup dalam arti luas dengan lebih baik. Begitu hebatnya id ini, sampai-sampai Freud berkata "man is what his sex is" (kulitas Laki-laki itu tergantung dari nafsu birahinya) (Adam, 2012).

Tokoh utama dalam cerpen Saga, yaitu tokoh Aku, merupakan seorang lesbian. Id seorang lesbian terlihat pada diri tokoh Aku. Rasa ketertarikan kepada sesama jenis menimbulkan keinginan untuk memenuhi kenikmatan. Id ditunjukkan oleh tindakan 
tokoh Aku yang tidak memedulikan normanorma yang ada dalam masyarakat dan agama, bahwa itu benar atau salah, susila atau asusila. Baginya, yang terpenting adalah ia dapat merasakan kebahagiaan kembali dan dapat mencapai kepuasan meski dengan risiko menimbulkan ketegangan baru khususnya masalah moral. Beberapa saat setelah perkenalan tokoh Aku dengan Aini di sebuah kafe di pinggir laut, tokoh Aku dengan berani melakukan tindakan yang tidak biasa dilakukan oleh seorang perempuan kepada teman perempuannya. Hal itu tergambar pada kutipan berikut ini.

Dan Aku tak tahu dari mana datangnya keberanianku, ketika suatu senja Aku mengecup tanganmu dan menggenggamnya lama-lama. Kau tampak terkejut tapi segera menikmatinya. Kita salah tingkah berdua. Tertawa tersipu, lalu berpandangan lagi. Ah...!

Kutipan di atas menggambarkan aspek id yang terlihat dari tindakan tokoh Aku yang dengan berani mengecup tangan Aini dan menggengamnya lama-lama. Tokoh Aku tidak peduli benar atau salah, dan tidak menimbang juga bagaimana reaksi yang akan diterimanya dari Aini. Ia ingin menuntaskan hasratnya untuk menyentuh Aini karena sejak awal mereka bertemu, tokoh Aku sudah merasa tertarik dengan Aini. Ternyata perasaan itu tidak bertepuk sebelah tangan yang dibuktikan dengan reaksi Aini yang menikmati kecupan dan genggaman tangan tokoh Aku.

Id tokoh Aku sebagai lesbian tidak berhenti di situ saja. Tokoh Aku tidak puas hanya dengan menggenggam tangan Aini saja, ia ingin memiliki tubuh Aini seutuhnya. Tokoh Aku sudah tidak sabar menanti datangnya saat itu. Hal itu dapat dilihat dari kutipan berikut ini.

Sudah seminggu Aku tak ke rumahnya. Dan hari ini kedua orangtuanya berangkat ke luar kota. Aku sudah tak tahan menunggu saat-saat indah ini.

Kutipan di atas menggambarkan aspek id tokoh Aku yang terlihat dari keinginan tokoh Aku untuk segera bertemu dengan Aini demi menuntaskan segala hasrat dan keinginannya selama ini. Moral dan norma sudah tidak penting lagi bagi tokoh Aku. Ia juga tidak mempedulikan statusnya sebagai seorang istri. Setelah seminggu tidak bertemu dengan Aini, akhirnya tokoh Aku dapat menyambangi kediaman Aini saat orang tua Aini bepergian ke luar kota. Itu adalah kesempatan indah yang ditunggu-tunggu dengan tidak sabar oleh tokoh Aku.

Akhirnya hasrat yang didorong oleh id terpenuhi juga. Tokoh Aku mencumbui jengkal demi jengkal tubuh Aini. Mereka berdua saling memuaskan hasrat seksual dan kenikmatan yang mereka inginkan. Hubungan intim yang tokoh Aku dan Aini lakukan merupakan cara untuk pemenuhan seksualitas layaknya persenggamaan yang dilakukan oleh laki-laki dan perempuan, hanya saja tidak ada pelibatan kemaluan sebagaimana yang dimiliki laki-laki. Dengan cara begitu, kenikmatan yang diinginkan mereka berdua dapat terpenuhi tanpa memikirkan salah benarnya tindakan itu dan risiko yang akan dihadapi apabila diketahui oleh orang lain. Sebagai pencegahan timbulnya risiko yang tak diinginkan, maka hasrat itu harus disalurkan secara sembunyi-sembunyi agar tidak ketahuan oleh orang lain. Gambaran pelampiasan hasrat seksual itu dapat dilihat dari kutipan berikut ini.

Kucumbu Aini sehingga seluruh tubuhnya mengejang, ah. Aku tahu ia masih sangat asing dengan hal ini. Lalu di atas sofa, kubimbing ia untuk mengenal suatu hal yang lebih indah. Sesuatu yang sakral. Aini menurut saja, tak menolak atau meminta. Dengan sangat perlahan dan halus kusetubuhi Aini, dengan caraku. Desahnya lembut membelai sukmaku. Aku lebur dalam gemulai tubuh Aini. Kami benarbenar menikmati. Terasa melayang di awan. Aku sempat membayangkan upacara serigala bersama Erald. Sangat jauh bedanya. Oh Aini. Aku benar-benar mabuk cintamu, mabuk tubuhmu.

Kutipan di atas menggambarkan aspek id tokoh Aku yang terlihat dari tindakan tokoh Aku yang mencumbui Aini di atas sofa. Aini yang baru pertama kali melakukan hubungan intim dengan perempuan, diajaknya untuk menikmati sesuatu yang indah, yaitu persenggamaan. Dengan sangat perlahan dan halus, tokoh Aku menyetubuhi Aini. Desah nikmat Aini sangat merdu merasuk sukma tokoh Aku. Aini dan tokoh Aku saling 
menikmati persetubuhan yang mereka lakukan. Bahkan, tokoh Aku sempat membayangkan dan membandingkan dengan persetubuhan yang dilakukannya dengan Erald, suaminya. Tokoh Aku tidak pernah bisa menikmati persetubuhannya dengan Erald. Hubungan antara Aini dan tokoh Aku dapat dikategorikan sebagai perselingkuhan mengingat status tokoh $\mathrm{Aku}$ yang sudah bersuami. Apalagi, ia berselingkuh dengan seorang perempuan yang notabene sama seperti dirinya. Namun, kesemua hal itu tidak dipedulikan oleh tokoh Aku. Norma dan moral tidak penting baginya.

Hingga malam harinya, saat tokoh Aku disetubuhi oleh Erald, ia masih terngiangngiang percintaannya dengan Aini di siang hari sebelumnya. Hal itu menjadi pelipur lara bagi tokoh Aku yang selalu merasa tersiksa saat ia dan Erald beradu tubuh. Hal ini dapat terlihat dari kutipan berikut ini.

Kucium tangan kiriku, dan seolah masih melekat di situ, kunikmati aroma cinta yang tadi siang kudapatkan. Wanginya membuatku melambung. Khayalanku melayang. Tak kupedulikan lagi siksa Erald atas tubuhku. Aku sedang menikmati sesuatu yang lain. Memoriku tentangnya berkelebatan. Wajah manis dengan dagu terbelah. Rambut pirang dan body yang aduhai. Kulitnya putih dengan leher jenjang. Ya, Aku bermain-main dengannya tadi siang. Dan kini bayangan Aini menari di pelupuk mataku, sementara Erald masih asyik mencambuki tubuhku dengan tubuhnya.

Kutipan di atas menggambarkan aspek id tokoh Aku yang terlihat dari tindakannya yang terus terbayang-bayang akan persenggamaannya dengan Aini bahkan saat tokoh Aku tengah bersetubuh dengan Erald, suaminya. Tangan kirinya seolah masih lekat aroma cinta Aini. Bayangan penampilan fisik Aini yang sangat memukau dan cantik menarinari di pelupuk matanya. Kenikmatan yang didapatnya dari Aini membuatnya terlena sehingga ia tidak memedulikan lagi siksa yang diberikan oleh Erald kepada tubuhnya.

Dari beberapa kutipan di atas, dapat disimpulkan bahwa dalam cerpen ini, id tokoh Aku sebagai lesbian terlihat. Rasa ketertarikannya kepada sesama jenis menimbulkan keinginan untuk memenuhi hasrat seksualitasnya bersama Aini dengan cara berhubungan seksual. Dengan melakukan hubungan seksual dengan Aini, proses kenikmatan itu dirasakannya dapat memberikannya kepuasan lahir dan batin, meskipun hal itu tidak sesuai dengan norma dan moral. Bahkan, kenikmatan seksualitas itu dapat secara totalitas dirasakannya walau hanya dengan cara membayangkan dan mengingat kembali puncak seksualitas kenikmatan yang telah dikecapnya bersama Aini.

\subsection{Ego}

Ego terperangkap di antara dua kekuatan yang bertentangan dan dijaga serta patuh pada prinsip realitas dengan mencoba memenuhi kesenangan individu yang dibatasi oleh realitas. Ego menolong manusia untuk mempertimbangkan apakah ia dapat memuaskan diri tanpa mengakibatkan kesulitan atau penderitaan bagi dirinya sendiri. Tugas Ego memberi tempat pada fungsi mental utama, misalnya penalaran, penyelesaian masalah, dan pengambilan keputusan. Dengan alasan ini, ego merupakan pimpinan utama dalam kepribadian yang mampu mengambil keputusan rasional (Minderop, 2010: 22).

Secara singkat menurut Bertens (2006: 33), tugas ego adalah untuk mempertahankan kepribadiannya sendiri dan menjamin penyesuaian dengan lingkungan sekitar, serta untuk memecahkan konflik-konflik dengan realitas dan konflik-konflik antara keinginankeinginan yang tidak cocok satu sama lain. Dengan kata lain, ego sebagai eksekutif kepribadian berusaha memenuhi kebutuhan id sekaligus juga memenuhi kebutuhan moral dan kebutuhan mencapai kesempurnaan superego.

Kaum homoseksual seringkali dipandang negatif oleh masyarakat. Tidak sedikit masyarakat yang menganggap homoseksual sebagai sebuah penyakit. Namun, sebenarnya homoseksual bukanlah sebuah penyakit melainkan hanya variasi seksual saja. Karena homoseksual bukanlah sebuah penyakit, homoseksual tidak bisa diobati. Oleh karena itu, tokoh $\mathrm{Aku}$ yang seorang lesbian ini, dengan aspek egonya, melakukan berbagai adaptasi dan penyesuaian agar dapat diterima 
oleh lingkungannya walaupun hal itu bertentangan dengan nurani dan kata hatinya. Sejak awal perkawinannya dengan Erald, tokoh Aku sudah bertekad untuk menjadi istri yang baik bagi suaminya, meskipun ia tidak mampu mencintai suaminya itu. Oleh karenanya, saat menghadapi kenyataan bahwa suaminya gemar menyiksa fisik dan batinnya, tokoh Aku lebih memilih untuk diam mengalah dan menerima dengan pasrah. Hal ini dapat ditemukan pada beberapa kutipan berikut ini.

Seperti raungan serigala yang mendambakan bulan purnama, kami menuntaskan hasrat yang sebenarnya buatku tak lebih dari upacara sang serigala itu sendiri. Aku, sang serigala yang selalu lunglai penuh luka setiap kali purnama berlalu.

Ya, dera di tubuhku selalu bertambah. Apalagi jiwaku. Luka-luka menganga. Darah mengalir deras di sana. Tak ada sepercik air hangat untuk menyekanya. Atau handuk lembut untuk mengeringkannya. Justru kadang air cuka dan jeruk asam sengaja dikucurkan Erald ke atas lukaku. Dan sesekali dalam mabuknya, ia menyelipkan lipan dan kalajengking ke dalam lukaku, jiwaku.

"Hei, kamu melamun apa?" Diguyurnya tubuh telanjangku dengan bir dingin. Sungguh pedih sebab mengenai puting payudara yang masih luka dia gigit hampir putus dua hari yang lalu. Aku menggigil menahan sakit. Kutatap langit-langit kamar.

Erald, manusia penyiksa itu sangat pecemburu. Akan sangat marah jika Aku ngobrol di telepon oleh seorang lelaki. Sejauh ini Aku tak pernah macam-macam dengan lelaki lain mana pun. Selain tak tertarik, sekali lagi, Aku tak ingin dibakar hidup-hidup oleh Erald jika ketahuan berselingkuh. Sementara Erald dengan cueknya menunjukkan celana dalam wanita yang ketinggalan di jok mobilnya. Aku hanya mengelus dada saja waktu itu. Tak cemburu dan tak marah saja. Aku sudah ambigu.

Kutipan di atas menggambarkan aspek ego yang terlihat dari kepasrahan tokoh Aku yang diam saja saat suaminya menyakitinya. Bahkan, ia bergeming saja saat ada celana dalam perempuan lain yang tertinggal di jok mobil suaminya. Tokoh Aku tidak menunjukkan perasaan marah dan kecewanya. Ia sudah ambigu. Tidak hanya secara psikis, secara fisik pun, Erald juga melukainya. Setiap dicumbui oleh Erald, bukan saja jiwanya yang sakit tersiksa, tetapi Erald juga melukainya secara fisik. Hal itu terbukti dengan puting payudara tokoh Aku yang nyaris putus karena digigit oleh Erald. Semakin sakit lagi saat Erald dengan sengaja menyiramkan bir dingin di atas lukanya itu. Namun, tokoh Aku hanya dapat menggigil menahan sakitnya. Sebagai seorang istri, ia sebenarnya berhak marah akan perlakuan Erald, tetapi ia sudah mati rasa karena telah terlalu lama tersiksa. Tokoh Aku juga tak berani berselingkuh dengan laki-laki lain mengingat suaminya yang gemar menyiksa. Aspek ego tokoh Aku di sini berperan menahan supaya tokoh Aku tidak melawan dan tidak berbuat hal-hal yang tidak menyenangkan hati Erald agar tidak semakin disiksa secara semena-mena. Aspek ego tokoh $\mathrm{Aku}$ juga mendorongnya untuk pasrah menerima keadaan serta mewujudkan citacitanya untuk menjadi istri yang baik dan penurut bagi suaminya.

Pernikahannya dengan Erald mendatangkan banyak kesengsaraan pada diri tokoh Aku. Pernikahan yang sebenarnya tidak pernah dikehendaki oleh tokoh Aku karena hanya memenuhi harapan dan norma dari keluarga dan masyarakat menyebabkan tokoh $\mathrm{Aku}$ tidak bahagia. Ketidakbahagiaannya tersebut bertambah dengan sikap dan perilaku Erald yang gemar menyakiti tokoh Aku dengan berbagai macam cara. Aspek ego tokoh Aku bertindak untuk memahami dan menerima realita serta menahan impuls tokoh Aku apabila ada keinginan untuk melawan. Ego tokoh Aku masih mendominasi untuk mewujudkan keinginannya menjadi istri yang baik dan penurut serta mau menerima keadaan yang tidak menyenangkan. Hal itu dapat terlihat dari kutipan berikut ini.

Kami lalu cair dalam dekapan semu yang selama bertahun-tahun ini kami lakukan. Kami menari dalam prisma emas berkilauan, namun tak memantulkan apa-apa selain kesedihan berwarna ungu pekat.

Kulihat arloji, masih jam 3 pagi. Tapi Erald telah menghidupkan compo-nya keras-keras, la baru pulang dari night club atau pub mana, Aku tak tahu. Aroma alkohol menusuk, berbaur dengan parfum perempuan-perempuan malam. 
Dibukanya paksa liang wanitaku. Tak diberinya Aku kesempatan untuk bersiap.

Dan serigala kembali melolong menyambut purnama. Aku lelah. Aku jenuh dengan upacara ini.

Beberapa kutipan di atas menggambarkan aspek ego yang terlihat dari tindakan tokoh Aku yang pasrah saja saat dicumbu oleh Erald, suaminya. Meski merasa tersiksa dan kesakitan karena Erald selalu menyakiti, tidak saja jiwa tetapi juga tubuhnya, mau tidak mau, siap tidak siap, ia harus melakukan kewajibannya sebagai seorang istri yang patuh kepada suaminya. Aspek ego tokoh Aku membuatnya berkompromi dengan keadaan dan menjalankan tugasnya sebagai seorang istri yang baik. Meskipun ia seorang lesbian, ia menikah dan mencoba bertahan dalam perkawinan yang tidak membahagiakan dengan laki-laki demi memenuhi tuntutan norma dan moral. Persetubuhannya dengan Erald dirasanya hanya sebuah ritual upacara saja. Tokoh Aku merasa jenuh dan lelah dengan persetubuhan yang sebenarnya tak pernah ia kehendaki. Jiwa tokoh Aku selalu merasa terluka dan sedih.

Selama delapan tahun berumah tangga dengan Erald, tokoh Aku tidak pernah merasakan bahagia. Derita dan siksa yang didapatnya membuatnya memutuskan untuk meninggalkan Erald. Namun, kesulitankesulitan yang didapatnya kemudian membuatnya harus berkompromi lagi. Aspek ego yang tadinya menginginkan untuk berpisah dengan Erald, akhirnya berubah menerima suratan takdirnya menjadi seorang lesbian yang berstatus istri dari suami yang gemar menyiksa. Hal itu dapat dilihat dari kutipan sebagai berikut.

Dulu Aku ingin mengakhiri. Jika Aku sebatang pohon, ternyata tak semudah itu melepaskan diri dari belitan akar yang telah tumbuh di tubuhku sendiri. Jadi kubiarkan saja ia tetap membelitku dengan belukarnya sekaligus.

Semak-semak yang kadang harus kubakar, terkadang membakar kulitku juga. Meski lebih sering ia menebang-nebang. Mencacah-cacah kulit kayuku. Membiarkan getah meleleh.

Sebenarnya matahari telah menuakan batangbatang kayuku, dan mengeringkan hijau daunku. Dahan-dahanku pun berjatuhan, dipungkasnya satu demi satu.
Kutipan di atas memperlihatkan aspek ego dari tokoh Aku yang berkeinginan untuk berpisah dengan Erald. Namun, ternyata untuk berpisah dengan suaminya tidak semudah yang ia bayangkan. Akhirnya, tokoh Aku menjadi pasrah menerima kenyataan takdirnya. Semakin ia berusaha melepaskan diri dari belitan Erald, semakin dirinya juga ikut terluka. Tokoh Aku sudah merasa lelah dan kehilangan gairahnya untuk hidup. Pelan-pelan jiwanya meranggas menunggu mati. Egonya pasrah menerima realita pahit kehidupan perkawinannya dengan Erald.

Pertemuannya dengan Aini membangkitkan gairah dan perasaan cinta yang telah lama mati suri di hati tokoh Aku. Ia merasakan gairah hidup lagi. Ego tokoh Aku terlihat dari keinginan-keinginan yang timbul karena keberadaan Aini. Hal itu dapat terlihat dari beberapa kutipan berikut ini.

Ingin kusambut sebuah dayung dan kuarungkan diri ke dalam lebarnya samudra, bersamamu. Menjauhi Erald, manusia penjajah yang hanya bisa mabuk dan menyiksa.

Akan kusahayakan diri ini beserta segenap hatiku untukmu. Aini, seandainya kau bersedia. Aku begitu terpikat senyummu. Dan kerling matamu memabukkanku. Mari. Aini. Mari kita tempuh perjalanan kita sejauh kita mampu. Mungkin Aku hanya ingin berlari dari Erald. Tapi tidak juga. Aku benar-benar terpikat oleh santun gayamu dan kerianggembiraan cakapmu. Tapi aduh Aini, dengan apa Aku akan pergi bersamamu, jika belitan Erald masih saja dan terus saja mencengkeramku begini?

Dan Aku berjanji tak akan meninggalkannya sendiri. Aku ingin mendampinginya sampai kapan pun.

Kutipan-kutipan di atas menggambarkan aspek ego dari tokoh Aku yang terlihat dari keinginan tokoh Aku untuk menghambakan hati sepenuhnya untuk Aini. Ia pun juga ingin berlari pergi menjauh dari Erald dan menyambut masa depan berdua bersama dengan Aini seorang. Tokoh Aku benar-benar terpikat oleh kesantunan dan keriangan Aini. Sampai kapan pun, tokoh Aku ingin selalu dapat mendampingi Aini dan tak akan pernah meninggalkannya. Ia berharap semoga suatu saat nanti ia dapat lepas dari belenggu jeratan Erald. 
Dari beberapa kutipan di atas, dapat terlihat bahwa dalam cerpen Saga ini ego yang dimiliki tokoh Aku berubah-ubah dan bervariasi. Pada awalnya, tokoh Aku ingin selalu berusaha dan terus berusaha untuk menjadi istri yang baik bagi Erald. Egonya pula yang membuatnya berkompromi dengan keadaan, selalu pasrah dengan segala dera kesakitan yang ditorehkan oleh suaminya pada tubuh dan jiwanya. Saat ia sudah tidak tahan lagi, egonya berubah menjadi keinginan dan usahanya untuk berpisah dengan Erald, tetapi tidak berhasil. Namun, keinginannya itu munncul lagi saat ia bertemu dengan Aini yang membuat jiwanya hidup dan merasakan cinta lagi. Eksistensinya sebagai pencinta sesama jenis atau lesbian bersinar lagi. Ego tokoh Aku menjadikannya ingin menghambakan hati dan diri sepenuhnya kepada Aini dan menjalani hidup berdua dengannya tanpa gangguan dari Erald.

\subsection{Superego}

Superego adalah aspek sosiologis kepribadian, merupakan wakil dari nilai-nilai tradisional serta cita-cita masyarakat. Superego lebih merupakan kesempurnaan daripada kesenangan, karena itu, superego dianggap sebagai aspek moral kepribadian. Fungsinya yang pokok ialah menentukan apakah sesuatu benar atau salah, pantas atau tidak, susila atau tidak, dan dengan demikian pribadi dapat bertindak sesuai dengan moral masyarakat. Meskipun masyarakat tempat individu hidup merupakan masyarakat yang tidak baik, tetap saja superego membentuk suara hati, yakni membedakan mana yang baik atau tidak baik. Superego pertama yang ditanamkan kepada individu berasal dari orang tua ketika seorang individu masih kanak-kanak (Suryabrata, 2005: 127)

Pribadi yang baik adalah pribadi yang memiliki sistem ego yang mampu menyeimbangkan id dan superego. Dominasi id ataupun superego akan membuat seorang individu memiliki karakter yang tidak baik. Dominasi salah satu dari sistem id, ego, dan superego akan memberi corak tertentu dalam individu. Dominasi dari id, misalnya, menyebabkan kepribadian individu tersebut tidak matang dan bercorak lust-principe sehingga individu tersebut dalam bertingkah laku akan cenderung tanpa pertimbangan dan selalu ditujukan kepada pencapaian kesenangan. Sedangkan apabila yang dominan itu superego, maka yang muncul adalah sebaliknya, yakni kepribadian individu yang moralistis, kaku, dan tidak realistis, dengan tingkah laku yang selalu dipertimbangkan, dan bahkan dihambat oleh kode-kode moral (Ferdinand, 2008: 110).

Aspek superego yang dimiliki tokoh Aku dalam cerpen ini terlihat saat ia berusaha untuk tampil sebagai perempuan "normal" yang berhubungan dengan laki-laki meski hatinya berkata lain demi memenuhi norma-norma yang dituntut darinya dan demi menjaga nama baik keluarga. Bahkan, ia mencoba menipu dirinya dengan menikahi seorang laki-laki demi kedoknya sebagai perempuan "normal" meskipun sebenarnya ia tidak merasakan kebahagiaan. Hal itu wajar karena oleh sebagian besar masyarakat, lesbian dianggap sesuatu yang menjijikan dan bahkan akan selalu mendapatkan cemoohan, sindiran, dan ejekan serta hal-hal negatif lainnya sehingga semakin meredupkan eksitensinya sebagai lesbian dan tidak berani menunjukkan jati dirinya sebagai pecinta sesama jenis secara terang-terangan. Dalam cerpen Saga, aspek superego tokoh Aku dapat ditemukan pada kutipan berikut ini.

Dan sakit itu hampir pudar ketika kukenal lelaki demi lelaki yang singgah menghampiriku. Aku hampa rasa pada mereka sebenarnya. Tapi demi menjaga reputasi di depan orangtua dan sanak keluarga, Aku tampil seolah perempuan normal, yang memuja lelaki, meski hatiku tertambat hanya pada Lorena yang kala itu sudah dibawa orangtuanya terbang entah ke kota apa. Hingga Erald, duda ganteng paling parlente dan modern di kampungku secara setengah memaksa meminangku. Aku menyerah saat itu. Dan berusaha sebaik mungkin menjadi istri yang baik untuknya. Meski akhirnya Aku kembali terluka. terlunta-lunta.

Kutipan di atas menggambarkan aspek superego tokoh Aku yang terlihat dari usaha tokoh Aku untuk menjadi perempuan yang dianggap "normal" dan seusai dengan harapan norma-norma dan agama meskipun sebenarnya hal itu bertentangan dengan kata 
hatinya. Demi menjaga nama baik dan reputasi keluarganya, tokoh Aku menerima pinangan dari seorang duda yang bernama Erald, yang kemudian menjadi suaminya. Tokoh Aku menyerah dan pasrah. Ia bahkan berusaha menjadi istri yang baik bagi suaminya meskipun hati dan tubuhnya terlunta-lunta.

Dalam konteks penyimpangan sosial, homoseksualitas dikatakan menyimpang karena fenomena tersebut tidak sesuai dengan norma dan nilai yang berlaku dalam banyak kelompok masyarakat. Homoseksual dianggap sebagai sebuah media yang tidak wajar demi mendapatkan kepuasan seksual. Penilaian masyarakat yang mengecam homoseksual diberikan dalam beberapa bentuk. Dari sudut pandang agama, homoseksualitas dianggap sebagai dosa. Dari sudut pandang hukum, dilihat sebagai penjahat. Dari sudut pandang medis terkadang masih dianggap sebagai penyakit. Hal-hal itulah yang membuat takut kaum homoseksual, mereka takut dikucilkan, dianggap penyakit, dan dianggap sebagai aib. Oleh karena itu, aspek superego mereka berperan dalam pengambilan tindakan yang berupa kepura-puraan sebagai manusia "normal" agar dapat diterima dalam masyarakat seperti yang terjadi pada tokoh Aku.

Id, ego, dan supergo tokoh Aku terlihat saling berusaha mendominasi satu sama lain dari waktu ke waktu. Hal itu adalah reaksi terhadap berbagai peristiwa yang terjadi dalam hidup tokoh Aku. Mulai dari perkawinannya dengan Erald, kehidupan perkawinannya yang tidak membahagiakan, hingga pertemuan dan kedekatannya dengan Aini. Tokoh Aku mengalami konflik kejiwaan yang cukup kompleks karena ketidakseimbangan antara id, ego, dan superego.

\section{Simpulan}

Berdasarkan analisis kepribadian tokoh Aku melalui kajian psikoanalisis di atas, dapat ditarik kesimpulan bahwa tokoh utama mengalami gejolak kejiwaan karena faktor orientasi seksual yang dianggap menyimpang, yaitu lesbian. Tokoh Aku mengalami ketidakseimbangan tiga komponen dalam struktur kepribadian yaitu id, ego, dan superego. Fungsi superego sebagai pengawas baik dan buruk, boleh dan tidak boleh, sudah tidak mampu bekerja dengan baik dalam menjaga keseimbangan peran id dan ego. Superego tidak lagi mampu bekerja karena besarnya desakan id. Sedangkan ego yang seharusnya berperan sebagai pengendali, memilih dorongan id untuk dipuaskan dan mencari cara untuk memuaskannya tanpa adanya peran superego yang bertugas untuk mengevaluasi baik dan buruk serta mengekang tindakan id, sehinga terjadilah tindakantindakan yang membuat tokoh utama mengalami gejolak kejiwaan.

Id tokoh Aku berupa hasrat dan rasa cinta yang begitu besar terhadap kekasih lesbiannya, yang kemudian selalu mendorong tokoh Aku agar selalu dapat bersama, menyentuh, dan bercinta. Dampak dari besarnya id dan ego yang mengalahkan superego yaitu tokoh Aku menginginkan berpisah dengan suaminya yang gemar menyiksa agar dapat bersama dengan kekasih lesbiannya dan keinginan tokoh Aku untuk mencumbui kekasih lesbiannya. Superego yang berfungsi sebagai pengawas baik dan buruk serta boleh dan tidak bolehnya sesuatu, tidak lagi berfungsi karena dikalahkan oleh id dan ego.

Sebenarnya, awalnya tokoh Aku sempat dikendalikan oleh superego sehingga ia mau menikah dengan laki-laki dan berusaha menjadi istri yang baik demi norma dan moral yang berlaku dalam masyarakat. Bahkan saat menjadi istri pun dorongan ego tokoh Aku membuatnya selalu berusaha untuk menjadi istri yang baik dan patuh pada suami. Namun, karena ternyata suaminya seorang penyiksa, ditambah dengan pertemuannya dengan perempuan yang kemudian menjadi kekasih lesbiannya, ego lain yang lebih dominan muncul, yaitu dorongan untuk meninggalkan suaminya dan hidup bersama berdua dengan kekasih lesbiannya. Terlebih lagi, id turut mendominasi kepribadian tokoh Aku yang terwujud dalam besarnya hasrat dan keinginan yang menggebu untuk menyentuh dan bercinta dengan kekasih lesbiannya. Superego tidak dapat berfungsi untuk mengendalikan dan merintangi cara kerja id dan ego tokoh Aku. 


\section{Daftar Pustaka}

Adam. 2012. Arti Id, Ego dan Superego. http://tugaspersonality.blogspot.co.id/2 012/11/arti-id-ego-dan-superego.html (diakses pada tanggal 21 Desember 2017 pukul 21.00).

Amalia, Nuriyah. 2014. "Analisis Tokoh Gambir dalam Novel Pintu Terlarang: Sebuah Tinjauan Psikologi Sastra". Program Sarjana Universitas Indonesia Depok.

Anshari, Hafi. 1996. Kamus Psikologi. Surabaya : Usaha Nasional.

Bertens, K. 2006. Psikoanalisis Sigmund Freud. Jakarta: Gramedia Pustaka Utama.

Budianta, Melani, dkk. 2008. Membaca Sastra: Pengantar Memahami Sastra Untuk Perguruan Tinggi (Cet. Ke-4). Magelang: Indonesiatera.

Departemen Pendidikan Nasional. 2008. Kamus Besar Bahasa Indonesia Pusat Bahasa. Jakarta: PT Gramedia Pustaka Utama.

Ferdinand, Zaviera. 2008. Teori Kepribadian Sigmund Freud. Yogyakarta: Prisma Sophie.

Kurniawan, Anton. 2016. Sejarah Singkat LGBT (Lesbi, Gay, Biseksual, dan Transgender).

http://antonkurniawan31.blogspot.co.id /2016/02/sejarah-singkat-lgbt-

lesbi.html. (diakses pada tanggal 21 Desember 2017 pukul 21.15).

Ikawati, Kartika. 2015. Kilas Balik 3 Dekade Organisasi LGBT Indonesia bersama Dede

Oetomo.

https://www.rappler.com/world/regions /asia-pacific/indonesia/85710-3dekade-lgbt-indonesia-dede-oetomo. (diakses pada tanggal 22 Desember 2017 pukul 18.00).
JP. 2008. "Seksualitas Lesbian". Jurnal Perempuan edisi 58. Jakarta: Yayasan Jurnal Perempuan.

Minderop, Albertine. 2010. Psikologi Sastra. Jakarta: Yayasan Pustaka Obor Indonesia.

Novrita, Misra dan M. Hendri. 2017. “Kajian Psikoanalisis dalam Novel Pria Terakhir Karya Gusnaldi”. Jurnal Pendidikan Rokania Vol. II (No. 1/2017): 79 - 89. Riau: STKIP Rokania

Rokhmansyah, Alfian. 2013. Studi dan Pengkajian Sastra. Malang: Graha Ilmu.

Rusli, Hetih. 2017. Menuju Kematian Fiksi $L G B T$.

https://jurnalruang.com/read/14962204 14-menuju-kematian-fiksi-lgbt. (diakses pada tanggal 22 Desember 2017 pukul 18.10).

Semi, M Atar. 1993. Metode Penelitian Sastra. Bandung: Angkasa.

Shadily, Hassan, 1989. Ensiklopedi Umum. Jakarta: Yayasan Kanisius.

Siswantoro, 2005. Metode Penelitian Sastra : Analisis Psikologi. Surakarta: Muhammadiyah Universitas Press.

Susilandari, E. 2009. "Living as lesbian in Indonesia: Survival Strategies and Challenges in Yogyakarta". Program Pascasarjana Universitas Gadjah Mada Yogyakarta.

Suryabrata, Sumadi. 2005. Psikologi Kepribadian. Jakarta: PT Raja Grafindo Persada.

Tuloli, Nani, 2000. Teori Fiksi. Gorontalo: BMT Nurul Jannah.

Wellek, R., \& Warren, A. 2014. Teori Kesusastraan. Jakarta: Gramedia.

Wicaksono, Andri. 2009. Pengkajian Prosa Fiksi. Surakarta: Garudha. 